JEN PENINAN MUTU

LEMBAGA PENJAMINAN MUTU

INSTITUT HINDU DHARMA NEGERI

DENPASAR

Volume 7 Nomor 12021

ISSN : 2407-912X (Cetak)

ISSN : 2548-3110 (Online)

http://ejournal.ihdn.ac.id/index.php/JPM

\title{
PENGEMBANGAN INSTRUMEN TRACER STUDY BERBASIS CLUSTER SEBAGAI KONTROL MUTU LULUSAN PERGURUAN TINGGI
}

\author{
Oleh \\ Muhamad Fakhrur Saifudin ${ }^{1}$, Meita fitrianawati ${ }^{2}$ \\ ${ }^{12}$ Universitas Ahmad Dahlan \\ ${ }^{1}$ fakhrur.saifudin@pgsd.uad.ac.id, ${ }^{2}$ meita.fitrianawati@pgsd.uad.ac.id
}

diterima 27 Agustus 2020, direvisi 29 Januari 2021, diterbitkan 28 Pebruari 2021

\begin{abstract}
The purpose of this research is to develop a cluster-based tracer study instrument that can be used to measure the absorption rate of graduates based on competency. This type of research is development. This study uses the ADDIE development model (Analysis, Design, Development, Implementation and Evaluation) $i$. The product appraisal instrument uses a quality assessment sheet involving material experts and an evaluation sheet which is used to determine the responses of stakeholders and graduates regarding the use of the product being developed. The type of data obtained is data about the process of developing a cluster-based tracer study instrument from the input of experts and graduates. The data analysis of this research used process data analysis and product quality data analysis. The results of the study were based on a feasibility test based on the material validator, assessment, and language validator which were assigned to the graduate assessment instrument with the criteria of "very suitable". The results of field trials showed the feasibility of the instrument as a tool for evaluating graduates was $86.5 \%$ so that it could be used as an alternative in tracing studies. These results are used as the basis for determining the success of higher education institutions in producing quality graduates
\end{abstract}

Keywords: Tracer Study, Mutu, Cluster

\section{PENDAHULUAN}

Tuntutan tentang kualitas lulusan perguruan tinggi menjadi perhatian penting pemerintah, institusi penyelenggara pendidikan, masyarakat baik lokal maupun nasional. Hal ini dengan belum maksimalnya lulusan perguruan tinggi (PT) di dunia kerja sesuai dengan kompetensi yang dimiliknya. Berdasarkan data human capital pada tenaga kerja Indonesia yang memiliki kualifikasi pendidikan tinggi berjumlah $11.01 \%$ (BPS, 2015). Hal ini menunjukkan bahwa kualifikasi pendidikan tinggi dengan ketercapaian kompetensi masih perlu adanya 
pemetaan dan peningkatan sebagai penjaminan mutu pendidikan.

Upaya pelacakan lulusan oleh perguruan tinggi selama ini hanya untuk memenuhi kebutuhan akreditasi yang bersifat administrasi. Selain itu, pelacakan lulusan hanya sebatas sejauh mana lulusan tersebut terserap di dunia pekerjaan. Ketercapaian kualitas lulusan tidak hanya pada indeks prestasi akademik yang baik, melainkan juga masa studi yang tepat, kesesuaian pekerjanan lulusan dan kompetensi lulusan yang mampu bersaing di dunia pekerjaan.

Permendikbud No. 49 tahun 2014 tentang standar nasional pendidikan tinggi yang menyatakan bahwa ketercapaian kualitas lulusan yang baik dipengaruhi salah satunya adalah tingkat kelulusan tepat waktu dan kesesuaian bidang ilmu dengan pekerjaan. Kegiatan tracer study bagian dari proses evaluasi untuk melihat pencapaian keberhasilan lulusan yang ditinjau dari aspek kesesuaian kompetensi lulusan oleh pengguna lulusan. Lebih lanjut, tracer study merupakan upaya untuk mencari informasi untuk menentukan kebijakan, perencanaan, dan pengambilan keputusan berkaitan dengan visi misi, kurikulum, proses pembelajaran dan kepuasan pengguna terhadap mutu lululsan.

Dewasa ini, tracer study menjadi kegiatan yang bersifat formalitas dan administratif. Beberapa perguruan tinggi telah menerapkan sistem online/daring dalam melakukan pelacakan. Tetapi instrumen yang dikembangkan masih bersifat untuk mengetahui sejauh mana tingkat keterserapan lulusan di bursa kerja. Jika kita tinjau lagi, Reni, dkk (2013) telah menganalisis bahwa upaya pelacakan dengan menggunakan sistem daring lebih mengedepankan pada keterserapan lulusan di dunia kerja. Selanjutnya, dalam temuan penelitian tersebut juga disebutkan bahwa upaya pelacakan alumni yang dilakukan secara daring mempunyai kelemahan yaitu partisipasi alumni yang belum optimal. Sedangkan kelebihannya adalah memudahkan untuk perolehan data pelacakan yang cepat dan akurat.
Data tracer study selain digunakan untuk melacak keterserapan lulusan juga berguna untuk mengetahui sejauh mana kompetensi lulusan dengan kurikulum yang telah diselenggaran di PT. Merujuk pada kurikulum KKNI bahwa lulusan harus sesuai dengan kerangka kualifikasi pendidikan yang telah ditetapkan oleh pemerintah. Berdasarkan studi pendahuluan bahwa mayoritas sebaran mahasiswa di PT memuat berbagai mahasiswa yang berasal dari luar daerah. Perguruan tinggi di Yogyakarta misalnya, lebih dari $63 \%$ mahasiswa berasal dari luar daerah. Hal ini tentunya berpengaruh terhadap perancangan kurikulum yang harus disesuaikan dengan kebutuhan pengguna/stakeholder.

Terkait dengan pentingnya pengembangan instrumen tracer study Ramirez (2014) telah menunjukkan bahwa lulusan mengklaim bahwa pengetahuan, keterampilan dan kompetensi yang diperoleh secara akademis memberikan kontribusi besar dalam kinerja mereka. Hal ini menunjukkan bahwa pentingnya perencanaan, implementasi visi misi, dan upaya pelacakan alumni untuk mengetahui keberhasilan pendidikan suatu PT. Selanjutnya, Pemba, Macfarlane, Mpembeni, Goodell, Kaaya (2012) dalam penelitiannya menunjukkan bahwa PT dapat mengumpulkan dan menggunakan data untuk menargetkan dan meningkatkan kualitas pendidikan untuk meningkatkan jumlah lulusan. Secara khusus, tingkat kelulusan akan menyimpulkan dan merekomendasi tentang kualitas universitas yang baik.

Berdasarkan hasil studi penduhuluan pada analisis tracer study tahun 2017 di Universitas Ahmad Dahlan Yogyakarta khususnya Prodi PGSD, didapatkan bahwa secara signifikan lulusan terserap dalam dunia pekerjaan. Namun demikian, beberapa temuan sebanyak $12 \%$ lulusan mendapatkan pekerjaan di luar kompetensi yang telah didapatkan di PT. Pada data tersebut, menunjukkan belum tersedianya lapangan pekerjaan di daerah tempat asal lulusan. Hal ini menjadikan lulusan perlu menggali lagi kompetensi yang belum dimiliki dengan 
melakukan program profesi maupun studi lanjut untuk memenuhi tuntutan dunia kerja.

Kegiatan pelacakan alumni yang telah diatur melalui Permendikbud No 19 tahun 2015 tentang standar proses. Kegiatan tersebut digunakan sebagai kontrol mutu lulusan yang meliputi kompetensi pengetahuan, sikap, dan keterampilan. Ketiga ranah tersebut dikembangkan menjadi sebuah instrumen tentang jauh mana tingkat keterserapan lulusan oleh pengguna. Beberapa perguruan tinggi telah mengembangkan dan melakukan pelacakan alumni baik secara onlineloffline.

Pengembangan instrumen pelacakan/ tracer berbasis clusterl kelompok. Pengembangan instrumen ini didasarkan pada kebutuhan lulusan pada kelompok/daerah tertentu terkait dengan kompetensi yang dimiliki berkorelasi positif terhadap kebutuhan kerja di daerah masing-masing. Selanjutnya, instrumen ini juga dapat digunakan sebagai perencanaan dan pengambilan keputusan PT untuk mengembangkan kurikulum yang sesuai kebutuhan lulusan. Tujuan penelitian ini yaitu, (1) mengembangkan instrumen tracer study berbasis cluster; (2) mendeskripsikan kelayakan instrumen sebagai kontrol mutu perguruan tinggi.

\section{METODE}

Jenis penelitian ini merupakan penelitian dan pengembangan atau (Reseacrh and Development). Produk yang dihasilkan dari penelitian ini berupa instrumen tracer study berbasis cluster. Dalam penyusunan ini menggunakan model pengembangan ADDIE yang terdiri dari Analysis (Analisis), Design (Perencanaan), Development (Pengembangan), Implementation (Implementasi) dan Evaluation (Evaluasi).

Jenis data yang diperoleh terdiri atas data tentang proses pengembangan instrumen berbasis cluster berdasarkan masukkan dari ahli, stakeholder dan lulusan. Selanjutnya, data tentang tingkat kualitas instrumen berbasis cluster berdasarkan lembar penilaian 3 orang ahli, serta hasil wawancara stakeholder dan lulusan. Analisis Data didasarkan pada data proses pengembangan produk instrumen berupa data deskriptif, dicermati, disusun dan ditabulasi. Analisis data proses pengembangan produk menggunakan analisis deskriptif kualitatif dan statistik deskriptif. Data kualitas produk menggunakan analisis lembar penilaian dengan cara sebagai berikut. Tabulasi data lembar penilaian kualitas instrumen diperoleh dari tiga orang ahli dan mengkonversi ratarata yang diperoleh menjadi nilai kualitatif.

\section{HASIL DAN PEMBAHASAN}

Hasil analisis penelitian ini dibagi menjadi tiga bagian yaitu (1) analisis kebutuhan; (2) pengembangan instrumen; dan (3) uji kelayakan produk. Produk yang dikembangkan yaitu instrumen tracer study berbasis cluster. Pengembangan produk didasarkan pada kebutuhan institusi yaitu perguruan tinggi untuk mengetahui aktivitas dan kinerja lulusan. Hasil analisis tersebut digunakan untuk bahan kajian menentukan kebijakan mutu PT. Kebijakan yang diambil antara lain penentuan visi dan misi PT, penentuan kurikulum, dan penentuan penciri khusus PT.

\section{Analisis Kebutuhan}

Analisis kebutuhan yang dilakukan dengan menggunakan studi referensi untuk menentukan arah dan desain instrumen. Instrumen dibuat sesuai kebutuhan yang didasarkan pada kebutuhan institusi PT. Instrumen tracer study yang telah ada masih umum dalam hal pertanyaan tentang aktivitas dan kinerja lulusan. Melalui pengembangan instrumen tracer study dalam penelitian ini, dipetakan berdasarkan cluster asal daerah lulusan. Melihat beragamnya mahasiswa dari Universitas Ahmad Dahlan, maka analisis kebutuhan dikembangkan berdasarkan cluster lulusan. Hasil angket tentang kebutuhan instrumen dibuat bekerja sama dengan BIMAWA UAD untuk mengkolaborasikan bagian instrumen yang belum terintegrasi dengan kebutuhan PT. Analisis kebutuhan dilakukan dengan hasil angket kebutuhan dengan responden lulusan, pengambil kebijakan, dan stakeholder yang ditampilkan pada Tabel 2. 
Tabel 2 Hasil Analisis Kebutuhan

\begin{tabular}{lll} 
Aspek & Setuju & Tidak setuju \\
\hline $\begin{array}{l}\text { Kebutuhan } \\
\text { instrumen } \\
\text { study }\end{array}$ & $77 \%$ & $23 \%$ \\
\hline $\begin{array}{l}\text { Kebutuhan kinerja } \\
\text { lulusan }\end{array}$ & $68 \%$ & $32 \%$ \\
\hline $\begin{array}{l}\text { Kebutuhan aktivitas } \\
\text { lulusan }\end{array}$ & $65 \%$ & $35 \%$ \\
\hline $\begin{array}{l}\text { Kebutuhan } \\
\text { pemetaan kebutuhan } \\
\text { berdasarkan cluster } \\
\text { wilayah }\end{array}$ & $75 \%$ & $25 \%$ \\
\end{tabular}

Berdasarkan Tabel 2 hasil analisis tersebut, bahwa kebutuhan instrumen tracer study yang kredibel, valid, dan aksesabel dikembangkan menjadi sebuah pertimbangan dalam penyusnan instrumen. Merujuk pada hasil tersebut, kebutuhan instrumen tracer sebesar $77 \%$ yang menandakan bahwa PT butuh sebuah kontrol mutu untuk mengetahui sejauh mana keberhasilan/output lulusan. Studi literasi digunakan unutk analisis kebutuhan untuk mementukan komponen dan indikator tracer study. Pemba, Macfarlane, Mpembeni, Goodell, Kaaya (2012) dalam penelitiannya menunjukkan bahwa PT dapat mengumpulkan dan menggunakan data untuk menargetkan dan meningkatkan kualitas pendidikan untuk meningkatkan jumlah lulusan. Secara khusus, tingkat kelulusan akan menyimpulkan dan merekomendasi tentang kualitas universitas yang baik. Berdasarkan studi pustaka tersebut bahawa universitas pelu melakukan pelacakan lulusan untuk mengkaji dan mengetahui keberhasil program pendidikan yang telah dilakukan.

\section{Pengembangan Produk}

Pengembangan produk instrumen tracer study dilakukan dengan model ADDIE dengan melakukan analysis situasi dan kebutuhan produk. Tahap design produk dilakukan dengan memetakan komponen dan indikator kebutuhan. Tahap development, dengan mengembangkan draf desain yang telah dibuat. Tahap Implementation, merupakan peujian instrumen dengan skala terbatas. Uji coba produk berguna untuk mengetahui kelayakan dan dan keterbacaan instrumen dengan melibatkan responden alumni yang berasal dari beberapa daerah. Tahap evaluation, digunakan untuk merevisi atas masukan pakar dan responden. Sehingga, produk yang dikembangkan menjadi valid, kredibel, dan aksesebel.

\section{Desain dan Pengembangan Produk}

Desain produk dikembangkan mengacu pada aspek tracer study yang telah dikembangkan oleh BIMAWA UAD dengan menambahkan beberapa komponen yang disesuaikan dengan cluster dan pendiri khusus lulusan. Adapun desain yang telah dibuat dengan mengacu pada Permendikbud No. 49 tahun 2014 tentang standar nasional pendidikan tinggi. Setelah dilakukan analisis kebutuhan dan pengumpulan data terkait dengan kebutuhan maka dapat diperoleh desain intrumen mengacu pada komponen ditampilkan pada Tabel 3.

Tabel 3. Penilaian Kelayakan Instrumen Tracer Study Berbasis Cluster Berdasarkan Pakar Materi.

\begin{tabular}{ll}
\hline No. & Komponen \\
\hline 1. & Identitas \\
\hline 2. & Rencana aktivitas lulusan \\
\hline 3. & Kesesuaian kompetensi \\
\hline 4. & Pekerjaan pertama \\
\hline 5. & Lama mencari pekerjaan \\
\hline 6. & Kondisi saat ini \\
\hline
\end{tabular}




\begin{tabular}{ll}
\hline 7. & Kesesuaian bidang pekerjaan \\
\hline 8. & Peluang pekerjaan di daerah asal \\
\hline 9. & Kontribusi PT dalam meningkatkan kompetensi lulusan \\
\hline 10. & Aktivitas lulusan selama menempuh studi baik akademik dan nonakademik \\
\hline 11. & Masukan lulusan terhadap PT \\
\hline
\end{tabular}

Berdasarkan pada desain yang ditampilkan pada Tabel 3, dikembangkan menjadi instrumen tracer study berbasis cluster yang bertujuan sebagai kontrol mutu PT. Setiap komponen dijabarkan menjadi butir-butir pertanyaan yang akan dijawab oleh responden. Pengembangan instrumen menggunakan skala angka, jawaban singkat, dan jawaban panjang.

Pemilihan dengan model tersebut, diharapkan memudahkan dan keleluasaan responden dalam menjawab. Instrumen tracer study berbasis cluster ini, dikembangkan mengacu pada kebutuhan PT dan borang akreditasi. Selain sebagai kontrol mutu PT, instrumen tracer study ini digunakan sebagai pemetaan kebutuhan dalam pengambilan kebijakan. Berbasis cluster mengacu pada daerah asal responden. Selanjutnya, pada isi instrumen tracer study ini cluster yang dimaksud juga diperuntukkan berdasarkan kebutuhan PT, baik analisis proses maupun hasil pembelajaran.
Pengembangan produk isntrumen ini juga dapat dijadikan sebagai instrumen awal untuk pemetaan lulusan yang berguna dalam penentuan kebijakan selanjutnya. Instrumen disusun didesain untuk mempermudah responden mengisi secara terbuka. Pada setiap komponen, diberikan keleluasaan responden dalam menjawab dan menentukan pilihan sesuai dengan kondisi nyata lulusan.

\section{Analisis Kelayakan Instrumen}

Produk yang telah dikembangkan melalui tahap desain sampai tahap pengembangan dilakukan secara bertahap mulai dari aspek analisis kebutuhan, studi referensi, dan draf desain instrumen. Validasi produk dilakukan melalui professional judgement rekan sejawat beberapa pakar yaitu pakar evaluasi, pakar materi, dan pakar kebahasaan/linguistik. Pakar evaluasi ditentukan berdasarkan konsentrasi dan dislipin keilmuannya yaitu evaluasi pendidikan dan manajemen pendidikan. Hasil dari analisis kelayakan instrument ditampilkan pada Tabel 4.

\section{Tabel 4. Penilaian Kelayakan Instrumen Tracer Study Berbasis Cluster Berdasarkan Pakar Materi.}

\begin{tabular}{|c|c|c|c|}
\hline No & Aspek & $\begin{array}{l}\text { Skor yang } \\
\text { diperoleh }\end{array}$ & $\begin{array}{l}\text { Skor } \\
\text { Maksimal } \\
\end{array}$ \\
\hline \multicolumn{4}{|c|}{ Komponen kelayakan isi } \\
\hline 1. & Relevansi dengan sasaran mutu PT & 4 & 4 \\
\hline 2. & Relevansi dengan capaian visi misi & 3 & 4 \\
\hline 3. & Kejelasan pertanyaan & 3 & 4 \\
\hline 4. & Keruntutan materi pertanyaan & 4 & 4 \\
\hline 5. & Cakupan kebutuhan borang akreditasi & 3 & 4 \\
\hline 6. & Kesesuaian kebutuhan lapangan & 3 & 4 \\
\hline 7. & Kesesuaian dengan evaluasi lulusan & 4 & 4 \\
\hline 8. & Kelengkapan komponen tracer study & 3 & 4 \\
\hline \multicolumn{4}{|c|}{ Komponen penyajian } \\
\hline & Mendorong responden untuk melengkapi isian butir pertanyaan & 4 & 4 \\
\hline & Keruntutan isi butir pertanyaan & 4 & 4 \\
\hline & Penyajian bersifat komunikatif dan interaktif & 3 & 4 \\
\hline & Kemudahan dalam pengisian & 3 & 4 \\
\hline & Kemudahan dalam variasi jawaban & 4 & 4 \\
\hline \multicolumn{2}{|c|}{ Jumlah skor } & 45 & 52 \\
\hline \multicolumn{2}{|c|}{ Persentasi kelayakan } & $86,5 \%$ & $100 \%$ \\
\hline \multicolumn{2}{|c|}{ Kriteria } & Sangat sesuai & \\
\hline
\end{tabular}


Berdasarkan angket validasi materi yang ditunjukkan pada Tabel 4, dapat disimpulkan bahwa produk instrumen tracer study berbasis cluster sudah layak untuk diuji cobakan. Hasil wawancara menunjukkan bahwa instrumen tracer study berbasis cluster dapat diterapkan sebagai alternatif studi pelacakan alumni dari
PT yang mempunyai basis lulusan dari berbagai daerah. Selanjutnya, pada data di atas, perolehan skor 45 atau setara $86,5 \%$ menjadi indikasi kelayakan instrumen tracer study berbasis cluster berdasarkan aspek materi dengan kriteria sangat sesuai.

\section{Tabel 5. Penilaian kelayakan instrumen tracer study berbasis cluster berdasarkan pakar evaluasi dan manajemen pendidikan}

\begin{tabular}{llll} 
No & Aspek & Skor yang diperoleh & Skor Maksimal \\
\hline 1. & Pengukuran kualitas lulusan & 4 & 4 \\
\hline 2. & Kelogisan butir pertanyaan & 3 & 4 \\
\hline 3. & Mendukung sasaran mutu PT & 3 & 4 \\
\hline 4. & Mengacu pada evaluasi kinerja & 3 & 4 \\
\hline 5. & Evaluasi berdasarkan cluster wilayah & 3 & 4 \\
\hline 6. & Memberikan peluang pengembangan lanjut & 3 & 4 \\
\hline Jumlah skor & 19 & 24 \\
\hline Persentasi kelayakan & $79 \%$ & $100 \%$ \\
\hline Kriteria & Sesuai
\end{tabular}

Pada Table 5 dapat dikaji dari sudut pandang ahli evaluasi didapatkan skor 19 atau (79\%) yang mengindikasikan bahwa instrumen layak untuk dijadikan alat evaluasi dan kontrol mutu PT dalam menentukan kebijakan selanjutnya. Lebih lanjut, bahwa instrumen tracer study yang dikembangkan telah memenuhi kebutuhan borang yang dijadikan sebagai alat ukur untuk menentukan keberhasilan kinerja lulusan setelah menempuh studi di PT.

\section{Tabel 6. Kelayakan Instrumen Tracer Study Berbasis Cluster Berdasarkan Ahli Kebahasaan.}

\begin{tabular}{llll} 
No & Aspek & Skor yang diperoleh & Skor Maksimal \\
\hline 1. & Penggunaan kalimat efektif & 4 & 4 \\
\hline 2. & Penggunaan diksi & 3 & 4 \\
\hline 3. & Penulisan Ejaan & 4 & 4 \\
\hline 4. & keterbacaan & 3 & 4 \\
\hline 5. & Kohesi dan koherensi paragraph & 3 & 4 \\
\hline Jumlah skor & 17 & 52 \\
\hline Persentasi kelayakan & $85 \%$ & $100 \%$ \\
\hline Kriteria & Sangat sesuai
\end{tabular}

Berdasarkan pada Tabel 6 validasi ahli kebahasaan menunjukkan hasil yang signifikan yaitu sebesar $85 \%$ atau sangat sesuai. Hal ini dibuktikan dari hasil angket yang telah dilakukan oleh validator. Perolehan hasil ini didasarkan pada aspek kebahasaan yang meliputi kelengkapan kalimat, diksi, EYD, gaya bahasa, dan kepaduan paragraf. Sehingga dari sudut pandang ahli bahasa, instrumen dapat digunakan sebagai alat kontrol mutu PT.
Selanjutnya, hasil dari uji terbatas yang telah dilakukan juga menunjukkan hasil yang signifikan. Hasil ini menjadi dasar bahwa suatu modul dikatakan sesuai dan layak digunakan. Pengujian skala terbatas yang telah dilakukan pada pertemuan alumni di Provinsi Bangka dan Belitung. Alasan dilakukan uji coba terbatas di provinsi tersebut yaitu pada sebanyak lebih dari $32 \%$ lulusan berasal dari daerah tersebut. Melalui uji coba lapangan tersebut diketahui bahwa 
instrumen tracer study berbasis cluster dapat digunakan untuk mengetahui kinerja alumni.

\section{Implementasi Instrumen Tracer Study Berbasis Cluster}

Produk yang telah divalidasi oleh pakar kemudian diimplementasikan pada skala terbatas. Pengujian produk dilakukan pada pertemuan alumni di provinsi Bangka dan Belitung, dimana setiap daerah diwakili 30 responden alumni. Hal ini dilakukan untuk mengetahui aspek keterbacaan, keakuratan data kinerja, dan aktivitas alumni. Bekerja sama dengan KAMADA (ikatan alumni) Bangka Belitung, instrumen tracer study berbasis cluster dibagikan dan diisi oleh alumni pada acara temu alumni. Respon alumni yang didapatkan dalam implementasi instrumen tracer study melalui angket tertutup dengan jawaban "Ya" dan "Tidak". Berdasarkan pengujian skala terbatas pada aspek tanggapan diperoleh hasil yang signifikan yaitu dengan kriteria "baik" dan "sangat baik". Adapun hasil dari implementasi instrument tracer study berbasis cluster ditampilkan pada Tabel 7.

Tabel 7. Tanggapan Alumni dalam Uji Terbatas.

\begin{tabular}{llll}
\hline No. & Pertanyaan & $\begin{array}{l}\text { Persentase } \\
\text { (Ya) }\end{array}$ & Kriteria \\
\hline 1. & Apakah instrumen menjawab kinerja lulusan? & 100 & $\begin{array}{l}\text { Sangat } \\
\text { baik }\end{array}$ \\
\hline 2. & Apakah instrumen tracer study sudah mewakili kondisi lulusan? & 90 & $\begin{array}{l}\text { Sangat } \\
\text { baik }\end{array}$ \\
\hline 3. & $\begin{array}{l}\text { Apakah tampilan instrumen tracer study menarik dan mudah } \\
\text { dibaca? }\end{array}$ & 80 & $\begin{array}{l}\text { Sangat } \\
\text { baik }\end{array}$ \\
\hline 4. & Apakah instrumen tracer study sesuai dari aspek bahasa? & 100 & $\begin{array}{l}\text { Sangat } \\
\text { baik }\end{array}$ \\
\hline 5. & $\begin{array}{l}\text { Apakah instrumen tracer study dapat dijadikan feed back untuk } \\
\text { kemajuan PT? }\end{array}$ & 85 & $\begin{array}{l}\text { Sangat } \\
\text { baik }\end{array}$ \\
\hline 6. & $\begin{array}{l}\text { Apakah instrumen tracer study dapat dijadikan bahan kontrol } \\
\text { mutu lulusan? }\end{array}$ & 80 & $\begin{array}{l}\text { Sangat } \\
\text { baik }\end{array}$ \\
\hline 7. & $\begin{array}{l}\text { Apakah instrumen tracer study sudah mewakili kebutuhan alumni } \\
\text { dari berbagai daerah? }\end{array}$ & 100 & $\begin{array}{l}\text { Sangat } \\
\text { baik }\end{array}$ \\
\hline 8. & $\begin{array}{l}\text { Apakah instrumen tracer study mudahkan alumni untuk } \\
\text { berinteraksi dengan alumni lain? }\end{array}$ & 100 & $\begin{array}{l}\text { Sangat } \\
\text { baik }\end{array}$ \\
\hline 9. & $\begin{array}{l}\text { Apakah instrumen tracer study mampu menjawab keluhan alumni } \\
\text { terhadap kebijakan PT? }\end{array}$ & 75 & Baik \\
\hline 10. & Menurut anda, sudahkah layak dijadikan pengukuran evaluasi? & 100 & $\begin{array}{l}\text { Sangat } \\
\text { baik }\end{array}$ \\
\hline & Rata-rata \% & $93 \%$ & $\begin{array}{l}\text { Sangat } \\
\text { baik }\end{array}$ \\
\hline
\end{tabular}

Pada data tersebut, dapat disimpulkan bahwa tanggapan alumni positif. Hasil yang didapatkan pada item pertanyaan nomor 2,3 , 5, 6, dan 9, beberapa mahasiswa menjawab belum sesuai. Sedangkan, item soal yang lain diperoleh persentase $100 \%$ dengan jawaban "Ya". Melalui hasil angket ini, diperoleh masukan dari alumni yang merasa perlu untuk dilakukan perbaikan produk. Perbaikan instrumen dilakukan bersifat parsial disesuaikan dengan masukan validator dan mempertimbangkan dari aspek pengguna yaitu alumni.

\section{Evaluasi Instrumen Tracer Study Berbasis Cluster}

Evaluasi penialaian validator berdasarkan produk yang dikembangkan. Penilaian ini digunakan sebagai acuan perbaikan demi kelayakan instrumen tracer study yang telah disusun. Untuk mengetahui kelayakan instrumen tracer study, pelibatan validator ahli materi, evaluasi, dan kebahasaan dilakukan secara bertahap melalui diskusi FGD. Diksusi FGD dilakukan untuk mengetahui dan menentukan perbaikan, sehingga instrumen yang dikembangkan menjadi layak untuk digunakan. 
Pada Tabel 4 tentang penilaian pakar materi dapat dijabarkan bahwa instrumen tracer study yang telah dikembangkan sangat sesuai dan layak dijadikan sebagai alat pengukuran keberhasilan kinerja lulusan sebagai kontrol mutu PT. Beberapa hal yang menjadi sorotan dalam penilaian tersebut meliputi kelayakan isi dan komponen penyajian. Pada diskusi pakar yang telah dilakukan, beberapa masukan yang dapat disimpulkan bahwa sebagai instrumen tracer study, mewakili kondisi alumni yang diukur dari masa kelulusan. Artinya, bahwa instrumen tracer study berisi aktivitas dan kirnerja alumni selama 2 tahun terakhir. Senada dengan Permendikbud No. 49 tahun 2014 tentang standar nasional pendidikan tinggi bahwa upaya pelacakan alumni atau lulusan dilakukan oleh PT untuk mengetahui kinerja dan aktivitas lulusan pada 2 tahun kelulusan. Sehingga didapatkan evaluasi kinerja PT dalam pengambilan kebijakan terkait visi, misi, kurikulum, dan pembelajaran.

Selanjutnya, upaya perbaikan yang dilakukan berdasarkan hasil masukan digunakan sebagai bahan acuan. Masukan dari validator ahli materi menyebutkan tentang perlunya kelengkapan komponen cluster yaitu pemetaan pertanyaan berupa penciri khusus cluster dan kebutuhan khusus lulusan. Berdasarakan masukan tersebut, Perbaikan yang bersifat menyeluruh dan bertahap tersebut telah dilakukan pada waktu revisi produk sebelum diujikan dalam skala terbatas.

Tabel 5 tentang penilaian validator ahli evaluasi menyebutkan bahwa instrumen tracer study sudah layak sebagai alat evaluasi lulusan untuk mengetahui kinerja dan digunakan sebagai kontrol mutu PT. Pada instrumen angket penilaian dikemukakan bahwa evaluasi yang digunakan berbasis kinerja. Hal ini dapat digunakan untuk mengetahui aktivitas lulusan baik dari aspek pekerjaan maupun penghasilan setelah menempuh studi di PT yang bersangkutan. Hasilnya digunakan sebagai bahan kajian PT untuk memperbaiki dan meningkatkan kualitas pelayanan akademik dan non- akademik untuk mencetak lulusan yang berkualitas.

Selanjutnya, Tabel 6 merupakan penilaian kelayakan validator kebahasaan yang berfungsi sebagai alat penyampaian dan penggunaan bahasa secara umum. Berdasarkan kriteria kelayakan yang diperoleh bahwa penggunaan bahasa dalam pengembangan instrumen tracer study berbasis cluster sangat sesuai. Beberapa masukan dari validator ahli kebahasaan yang dapat dihimpun antara lain penggunaan kalimat tanya pada butir pertanyaan, keteracaan kalimat, dan kohesi koherensi paragraf. Hasil masukan tersebut dijadikan bahan acuan dalam perbaikan.

\section{SIMPULAN}

Prosedur pengembangan instrumen tracer study berbasis cluster sebagai kontrol mutu lulusan PT meliputi beberapa tahap. (1) tahap analisi kebutuhan; (2) tahap studi referensi; (3) tahap desain produk; (4) tahap validasi desain dan implementasi; (5) uji skala terbatas; dan (6) evaluasi. Hal ini dilakukan sebagai upaya mengoptimalkan waktu, tenaga, biaya, dan pikiran dalam pengembangan produk instrumen tracer study berbasis cluster sebagai kontrol mutu lulusan PT.

Berdasarkan uji kelayakan yang didasarkan dari validator ahli materi, evaluasi, dan kebahasaan dinyatakan untuk instrumen evaluasi lulusan dengan kriteria "sangat sesuai". Dengan hasil ini, dijadikan pijakan untuk mengetahui keberhasilan PT dalam mencetak lulusan yang berkualitas.

\section{DAFTAR PUSTAKA}

Badan Pusat Statistik. (2015). Human Capital of Indonesia.

Carier Development Center (CDC UAD). (2016). Analisis Tracer Study Tahun 2016. Yogyakarta: UAD.

DIKTI. (2003). Pedoman Penjaminan Mutu Perguruan Tinggi.

Elassy, N. ( 2014). A model of student involvement in the quality assurance system at institutional level. Quality 
Assurance in Education, 21(2), 162198. [Accessed 21 Mei 2017].

Widoyoko, eko Putro. (2009). Evaluasi Program Pembelajaran Panduan Praktis Bagi Pendidik dan Calon Pendidik. Yogyakarta: Pustaka Pelajar.

Flomo Jr, J.S. (2013). "Aligning Higher Education to Workforce Needs in Liberia: a Tracer Study of University Graduates in Liberia". Dissertation. University of Minnesota.

Mavhunga. P. J \& Mazodze. (2014). “Quality of Educational Provision in Fast Track resettlement schools in Zimbabwe: A Case Study of Chiwodza Primary School". European Scientific Journal. Vol 1. p. 438-448. [Accessed 25 Mei 2017].

Millington, (2010). "Wikieducator," Open Education Resource Foundation, 1 June 2010.

Available: http://wikieducator.org/images/e/e1/PI D_424.pdf. [Accessed 25 February 2013].

Mugwisi, Tinashe \& Hikwa, Lawton. (2015).

"A Tracer Study of Master of Science in Library and Information Science Graduates from the National University of Science and Technology, Bulawayo, Zimbabwe". Afr. J. Lib. Arch. \& Inf. Sc.
Vol. 25, No. 2 (October 2015) p.173183.

Molenda, M. (2003). "In search of the ellusive ADDIE model". Performance improvement, 42 (5), 34-36. [Accessed 25 Mei 2017].

Pemba, Senga et al. (2012). "Tracking University Graduates in the Workforce: Information to Improve Education and Health Systems in Tanzania”. Journal of Public Health Policy Vol. 33 P. 57 www.palgrave-journals.com/jphp/

Permendikbud No. 49 Tahun 2014 tentang Standar Nasional Pendidikan Tinggi.

Permendikbud No. 19 Tahun 2015 tentang Standar Proses Pendidikan Tinggi.

Ramirez, Thelma L; Cruz, L.T; Alcantara, N.V. (2014). "Tracer Study of RTU Graduates: An Analysis". Journal of Arts, Science \& Commerce Vol. V, Issue - 1, Jan. 2014. Diakses 17 Maret 2017.

Renny, dkk. (2013). "Exploring Tracer Study Service in Career Center Web Site of Indonesia Higher Education". International Journal of Computer Science and Information Security Vol. 11, No. 3, diakses 16 Maret 2017.

Sugiyono. (2015). Metode Penelitian Kuantitatif, Kualitatif, Dan $R \& D$. Bandung: Alfabeta. 